\title{
Land Use and Land Cover Dynamics in Central River Region of the Gambia, West Africa from 1984 to 2017
}

\author{
Omar Ali Bah ${ }^{1, *}$, Tidiani Kone ${ }^{2}$, Sidat Yaffa $^{3}$, Mamadou Lamine Ndiaye ${ }^{4}$ \\ ${ }^{1}$ WASCAL Graduate Research Program in Climate Change and Biodiversity, University of Felix Houphouët-Boigny, Abidjan, Cote d'Ivoire \\ ${ }^{2}$ UFR Environment, University of Jean Lorougnon Guede, Daloa, Cote d'Ivoire \\ ${ }^{3}$ School of Environmental Sciences, University of The Gambia, Brikama Campus, Banjul, The Gambia \\ ${ }^{4}$ Laboratory of Geoinformation (LERG), Polytechnic High School, Cheikh Anta Diop University, Dakar, Senegal
}

Email address:

Oabah87@hotmail.com (O.A.Bah),bahomara@gmail.com (O.A. Bah), oabah.b2@wascal-ci.org (O.A. Bah),

bah.a@edu.wascal.org (O.A. Bah)

${ }^{*}$ Corresponding author

\section{To cite this article:}

Omar Ali Bah, Tidiani Kone, Sidat Yaffa, Mamadou Lamine Ndiaye. Land Use and Land Cover Dynamics in Central River Region of the Gambia, West Africa from 1984 to 2017. American Journal of Modern Energy. Vol. 5, No. 2, 2019, pp. 5-18.

doi: $10.11648 /$ j.ajme.20190502.11

Received: March 13, 2019; Accepted: April 28, 2019; Published: June 4, 2019

\begin{abstract}
This study is focused on land use and land cover dynamics observed in Central River Region. It aims to determine the direction and rate of change in land use as a means of assessing the impact of climate change in Central River Region (CRR) of The Gambia. Decadal satellite images were used to measure changes in land use and land cover from 1984 to 2017 using supervised classification. Eight land use and land cover types were identified and mapped in this study namely: Crop lands, Gambia River, Halophytic vegetation, Irrigated crops, Mangrove, Settlement, Shrub/Wood savanna and Wooded savanna. The areas of crop lands, halophytic vegetation and settlement expanded between 1984 and 2017. River Gambia, irrigated crops, mangrove, shrub/wood savanna and wooded savanna areas decreased during the same period. Transition to less savanna was higher than transition to more settlement. In addition, physicochemical parameters were analyzed during the rainy and dry seasons for correlation with climate data. Socioeconomic surveys based on structured questionnaires were also conducted with 70 households in 6 villages in CRR. Land clearing for agriculture, tree cutting for firewood and charcoal, settlement and livestock grazing were mainly cited by the respondents as the main culprit inducing land cover change in CRR. This study shows that deforestation and forest degradation are still in progress despite the implementation of a management plan for a full rotation. We therefore proposed best management practices in order to control the agricultural clearing of land in the region such as agricultural intensification and soil fertility improvement.
\end{abstract}

Keywords: Satellite Images, Land Use Land Cover, CRR, Supervised Classification, Vegetation

\section{Introduction}

The rate of change and direction of land use and land cover change in Sub-Saharan Africa (SSA) are unpredictable and quite fast [1]. This is due to the fact that land use and land cover changes are both natural and anthropogenic. Among the two, the most common causes of land use and land cover change is the continuous use of natural resources by the people to meet their basic needs and wants especially in SSA where local's livelihood most often depend on natural resources $[2,3]$. This change in land use and land cover causes to a large extend the degradation of the natural environment and ecosystem services and goods that usually support people basic needs $[4,5]$. Land use and land cover change have a major challenge to communities that mainly depend on natural resources for their needs and sustainable livelihoods aspirations. To remedy this situation, strategies to cope with the issue and a good understanding of the direction of change and the extent are fundamental.

According to Meshesha et. al and Agarwal et. al, land use is the human intervention on land $[6,7]$. This involves 
both the way in which the land is manipulated and the intent that motivated that manipulation [8]. Land cover on the other hand is the biophysical attributes of the earth's surface including but not limited to biota, surface water, ground water, soil, topography, and human structures [810]. Causes of land use and land cover change are summarized mainly in two categories, that is proximate/ direct causes and the underlying/indirect causes [11- 14]. Theses underlying causes are factors that trigger the proximate causes and are referred to as economic, demographic, institutional, political factors that mainly occur at regional or global scales [15]. Contrary to the underlying causes, the proximate causes are the immediate actions that affects directly the land cover [16-18]. The common causes of land use land cover are many but the most cited literature in Africa are agricultural use, wood extraction and infrastructure establishment [14, 19-23]. Apart from forest clearing for agricultural purpose, wood extraction mainly for household energy consumption is the major driving force of vegetation dynamics in SSA countries $[24,25]$. On the other hand, wood fuel whether used directly as firewood or converted into charcoal is the primary source of domestic energy [26]. Despite the capacity of tropical forest species to regenerate after cutting for charcoal to allow forest recovery, the pressure exerted by charcoal production results in devastating ecological and environmental effects especially deforestation and forest degradation [27-32].

The idea of land-cover/land use change has taken place from time immemorial when mankind shifted from goods harvesting in the wild into the production of its own goods to meets his daily requirements [33]. From then on, natural vegetation were progressively converted into agricultural land for crop production, animal grazing and other land use types [33]. This, due to rapid increasing of the population demography during the last two centuries and subsequent land requirement for farming and urbanization, important amount of forest was converted into anthropogenic sites $[15,33]$. The rate at which land degradation of primary ecosystems and associated biodiversity decline has been alarming during the two last centuries [34]. A recent publication by FAO estimated that worldwide forest cover lost about 13 million hectares per year during the last decade 2000-2010 with a persistent high decreasing rate in sub-Saharan Africa of which The Gambia is no exception [35].

The environmental effects of deforestation many a time prompt countries with high dependence on fuel wood to develop strategies for adapting with the menace. The Gambia, which is a major charcoal producing country, the concern for the unsustainable production of charcoal and the need to halt the process of deforestation and forest degradation caused by charcoal production led to community forest management so as for the community to take ownership of their forest [36].

In The Gambia, previous studies have assessed the vegetation dynamics in Tanbi Wetland National Park on mangroves [37]. They showed that mangrove cover decreased by $6 \%$ while grassland increased by $56.4 \%$ over the period covering 1973-2012. However, no specific study has tackled so far the land cover/land use change in CRR of The Gambia although this remain a great concern to sustainably design conservation strategies for a limited land cover. Therefore, this study was carried out as a case study of land cover/land use change in CRR of The Gambia in 2017 to assess the long- term changes of vegetation in relation to the climate-induced changes in the freshwater of the river from 1984 to 2017.

\section{Materials and Methods}

\subsection{Description of the Area of Study}

The Gambia is a small Sahelian country, bordered by Senegal and extending to the Western Coast of Africa between $13^{\circ}$ and $14^{\circ} \mathrm{N}$. It covers a total land area of approximately 10,689 sq. $\mathrm{km}$ with a length of about 400 $\mathrm{km}$ and a width varying between $24-50 \mathrm{Km}$. According to the 2013 National Population and Housing Census, The Gambia's population is estimated at 1.8 million people with a population growth rate of $2.8 \%$ per annum. The climate of The Gambia is a Sudano-sahelian type of climate, with a short rainy season from June to October and a long dry season lasting from November to May. The average annual rainfall is $900 \mathrm{~mm}$ [38]. There has been an average reduction of $27 \%$ in the annual average rainfall since 1951 [38]. The mean temperature is $25^{\circ} \mathrm{C}$. The study area (Figure 1) is located in the Central River Region (CRR) of The Gambia. Prominent land use types include: agricultural lands; settlement areas; rice cultivation and cruising boat for river transportation. It is one of the six Regions in the country. The CRR consists of ten local administrative districts headed by a District Chief called Seyfo. According to the 2013 census, 226,018 inhabitants live in the Central River Region of The Gambia [39]. The area is characterized by good soil structure and fertility and has some vegetative cover compared to the rest of the country especially the Northern part [40].

Virtually all residents in the CRR depend directly or indirectly on the agricultural sector and poor or failed harvests seriously threaten the food security in the area. Because of its vulnerability (high dependence on agriculture), the Central River Region was chosen as the focus of this case study. 


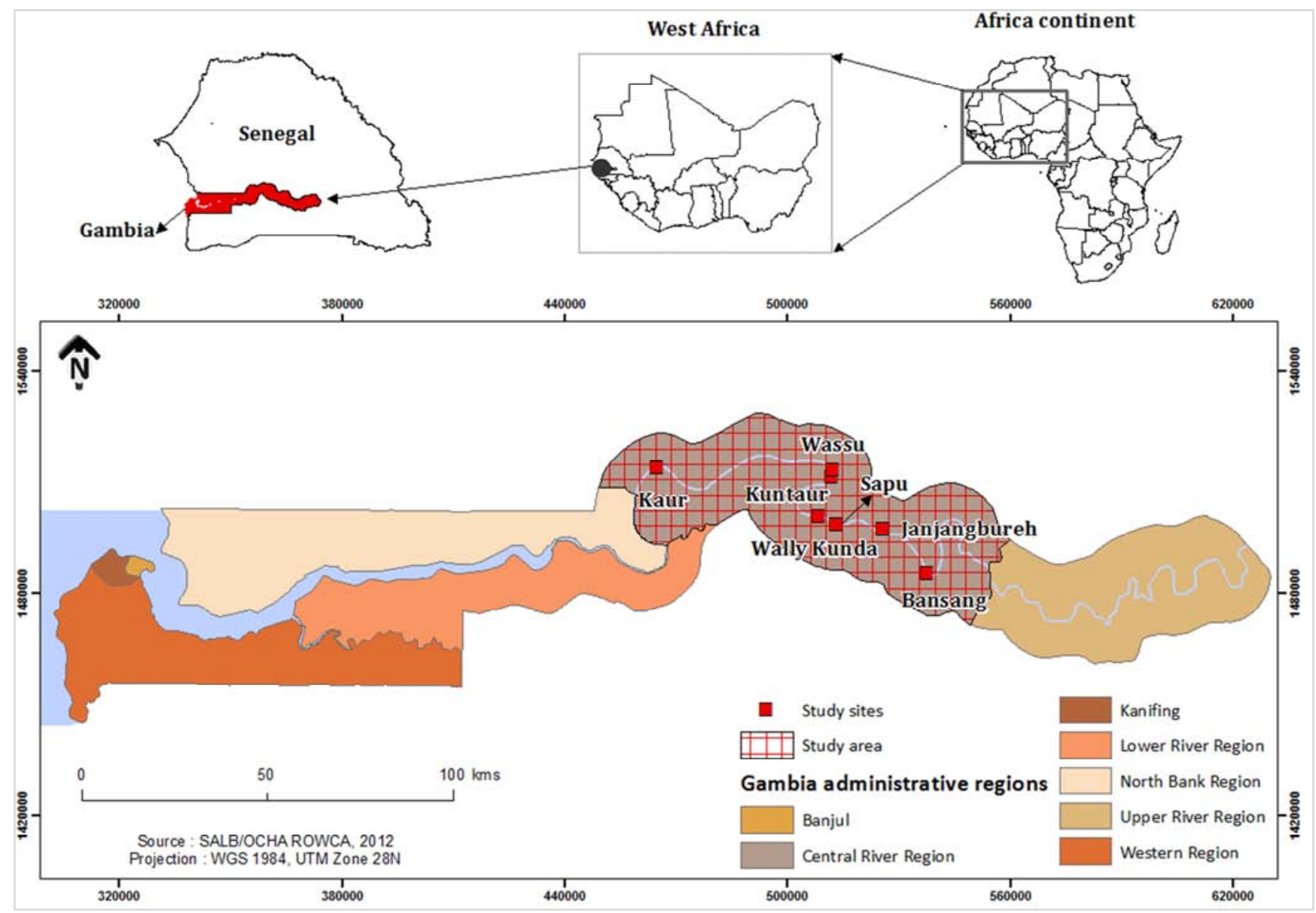

Figure 1. Location of Central River Region in The Gambia, with the six study sites marked (red).

\subsection{Sampling Design}

Six sampling sites were identified to be representative of Central River Region (Table 1). Land use types in the study area include Crop lands, Gambia River, Halophytic Vegetation, Irrigated crops, Mangrove, Settlement, Shrub/wood savanna and Wooded savanna. To ensure a uniform representation of the hydrological regime of the study area, a straight-line transect method was used to sample water quality parameters at each of the study sites [41]. Three transects were set perpendicular to the water source at each sampling point adapted from Louca et. al [42]. In each transect, three plots were set to give 9 plots per sampling point / village.

Table 1. Sampling sites with GPS coordinates in CRR.

\begin{tabular}{ll}
\hline Sampling Sites & GPS Coordinates \\
\hline Wally Kunda & N 13.57321 W 014.92249 \\
Bansang & N $13.57330 \mathrm{~W} 014.92294$ \\
Janjanbureh & N 13.54368 W 014.76309 \\
Wassu-Darka & N 13.69576 W 014.89130 \\
Kuntaur & N $13.68670 \mathrm{~W} 014.87980$ \\
Kaur & N $13.69271 \mathrm{~W} \mathrm{015.32516}$ \\
\hline
\end{tabular}

\subsection{Environment/Water Quality Analysis}

Three samples were collected from each sampling sites in a diagonal mode $(n=27)$ to ensure uniformity in water samples. All water samples were collected during high tide at a depth of $10-25 \mathrm{~cm}$ ) for measurement of physicochemical parameters since no significant vertical stratification was reported in the River Gambia [43, 44]. Dissolved oxygen, $\mathrm{Ph}$, temperature, conductivity and TDS were measured in-situ using a Multi-probe water meter (YSI Proplus) and turbidity was measured using a $\mathrm{HACH}$ turbidity meter $(\mathrm{HACH}$ 2100P). Water samples were also collected in clear polyethylene bottles, wrapped in foil and stored in ice boxes for transport to the laboratory for nutrients analysis. Nutrient analyzes were done using a $\mathrm{HACH}$ spectrophotometer (DR/2010) with Phos VerR 3 reactive reagent (ascorbic acid method) and Nitra VerR 5 (cadmium reduction method) for phosphate and nitrate. Sampling was done during peak discharge period of the River Gambia (September-December, 2017) and repeated during the peak dry season (April-July, 2018) to represent the seasonal cycle.

\subsection{Data Collection}

\subsubsection{Socio Economic Data}

A survey based on structured questionnaires were conducted in Northern part of the villages of Kaur, WassuDarka and Kuntaur and in the Southern part in the villages of Janjanbureh, Bansang and Wally Kunda. A total of 70 
household were randomly selected in the targeted villages. Apart from socio-demographic characteristics of the household (age of the

household chief, household size, household active population size, household head education level, ethnic group, gender, etc.), interviewees were also asked questions about their perception about land use/ land cover changes in CRR during the last ten years.

\subsubsection{Land Use Land Cover Map Acquisition \\ i. Remote Sensing and Field Data}

The dynamics of the land use and land cover were studied using time series of Landsat images. The images were obtained from Landsat MSS (Multi Spectral Scanner) of 1984, TM (Thematic Mapper) of 1994 and 2007 and Landsat OLI (Operational Land Imager) of 2017 corresponding to scene 204/050 \& 051 and 203/051 (Table 2). All the images were acquired approximately at the same period, during the peak dry season to ensure that the phonological stages of plant cover were not too different between dates. Similarly, peak dry season is the most suitable period to distinguish the various Sudano-Sahelian land -cover types because the contrast between the croplands and the natural environment is more distinguished [45]. Again, images captured during dry season have advantage of low land cover. Images used in this study were downloaded from the United States Geological Survey (USGS) Landsat Earth Resources Observation Systems (EROS) Data Center via the website (https://earthexplorer.usgs.gov/). A ground trothing was also carried out during the dry season in conformity to the period of image acquisition. A set of 88 Global Positioning System (GPS) points were collected in the six different study sites and the vegetation types were identified based on the classification of Aubreville [46].

Table 2. Details of the satellite data used in this research.

\begin{tabular}{|c|c|c|c|c|c|}
\hline Satellite & Sensor & Path/Row & Cell size (m) & Date of acquisition & Sources \\
\hline \multirow{2}{*}{ Landsat 5} & \multirow{2}{*}{ MSS } & $204-51$ & 60 & $03-05-1984$ & USGS \\
\hline & & $204-50$ & 60 & 03-05-1984 & USGS \\
\hline \multirow{3}{*}{ Landsat 5} & \multirow{3}{*}{$\mathrm{TM}$} & $203-51$ & 30 & 24-05-1994 & USGS \\
\hline & & $204-50$ & 30 & 13-04-1994 & USGS \\
\hline & & $204-51$ & 30 & $15-05-1994$ & USGS \\
\hline \multirow[b]{2}{*}{ Landsat 5} & \multirow[b]{2}{*}{$\mathrm{TM}$} & $203-51$ & 30 & $28-05-2007$ & USGS \\
\hline & & $204-50$ & 30 & $19-05-2007$ & USGS \\
\hline \multirow{3}{*}{ Landsat 8} & \multirow{3}{*}{ OLI } & $203-51$ & 30 & $07-05-2017$ & USGS \\
\hline & & $204-50$ & 30 & 28-04-2017 & USGS \\
\hline & & 204-51 & 30 & 28-04-2017 & USGS \\
\hline
\end{tabular}

\section{ii. Image Processing}

Visual analysis that corresponds to the traditional method of photo-interpretation of the satellite images were done. This analysis consists of identifying the different homogenous units [47]. This was made easy by our understanding of the vegetation and field surveys. The images used were all georectified to UTM WGS 84 Zone 28 North coordinates with radiometric corrections. Landsat images used in this study have undergone several pre-processing stages. First, the images were geometrically corrected and geocoded to the WGS Datum 1984 and Universal Transverse Mercator (UTM) Zone $28 \mathrm{~N}$ coordinate system. Then, the scenes were mosaiked to form a complete image of the study area given that it is straddling three scenes (203-51, 204-50 and 204-51). The automatic method based on the connection of georeferenced Landsat scenes has been applied through the ENVI software (version 5.1, ITT Corporation). However, the processing of the initial images will therefore go through a rebalancing of the contrasts (dynamic spreading) and a harmonization of the histograms. The study area was then extracted from the scene to determine the land cover and land use types by classifying the images.

A supervised classification was performed using the maximum likelihood algorithm and the most recent image of 2017. The supervised classification was chosen due to our understanding of the study area. The classification was parameterized by digitizing training areas. Prior to the determination of training areas, the number of classes was defined. The determination of the number of classes was based on the unsupervised classification performed up stream and the information collected in the field. To homogenize the classification, the images were subjected to $3 \times 3$ pixels filter. To check the accuracy of the classifications, a confusion matrices was created for each year to determine the overall accuracy and the kappa coefficient. The accuracy assessment showed good classification with kappa coefficient and an overall accuracy greater than $70 \%$ for the 2017 image taken as reference. All the processing was performed using Envi 4.7.

To highlight more information about the selected images, visual interpretation assisted by computer method is selected to map the different land use land cover classes. In addition, visual interpretation is still one of the most widely used methods for detecting, identifying and characterizing the spatial features on an image since human brain is a good interpreter of images. Some classes were spectrally confused and could not be separated well by supervised classification and hence visual interpretation was required to separate them. In order to facilitate classification using visual interpretation assisted by computer method, all images were first segmented on ENVI, then exported as a shapfile, to be grouped into land use land cover classes through ArcGIS 
software (version 10.2, ESRI Inc)

The classified images were vectorized and processed using Arc GIS to produce land cover maps for the different periods. The post-classification comparison which is the most appropriate way to compare multi-source data was used for change detection analysis [45]. The analysis of the land use and land cover change was done taking into consideration the modifications and conversion processes observed between the different periods. Modifications refer to changes that affect the character without changing the category while conversions concern the replacement of one category by another [12]. A second temporal analysis of transition among vegetation types was carried out to determine the proportion of transition to less and more wooded vegetation.

Representative pictures were also taken for different land uses/land cover (Figure 2). Additional data were collected to facilitate easy exploitation of the images and for familiarization with the work environment. These include historical data about the CRR from literature and those generated from the images [39]. Layers were digitized from the panchromatic images.

Ancillary data such as information of administrative boundaries such as important towns, villages and roads and highways were digitized using Gambia Topo- maps on 1:50000 scale to prepare the base map. The Gambia topo sheet was geo-referenced using the UTM-Zone 28 North coordinate system and the WGS84.

Analysis of the image was carried out using ArcGIS 10.2 and ERDAS Imagine 12. The images were analyzed base on texture. The following indices were generated; Difference Vegetation Index (NDVI), Supervised and Unsupervised image classification, Accuracy assessment and Kappa coefficient.
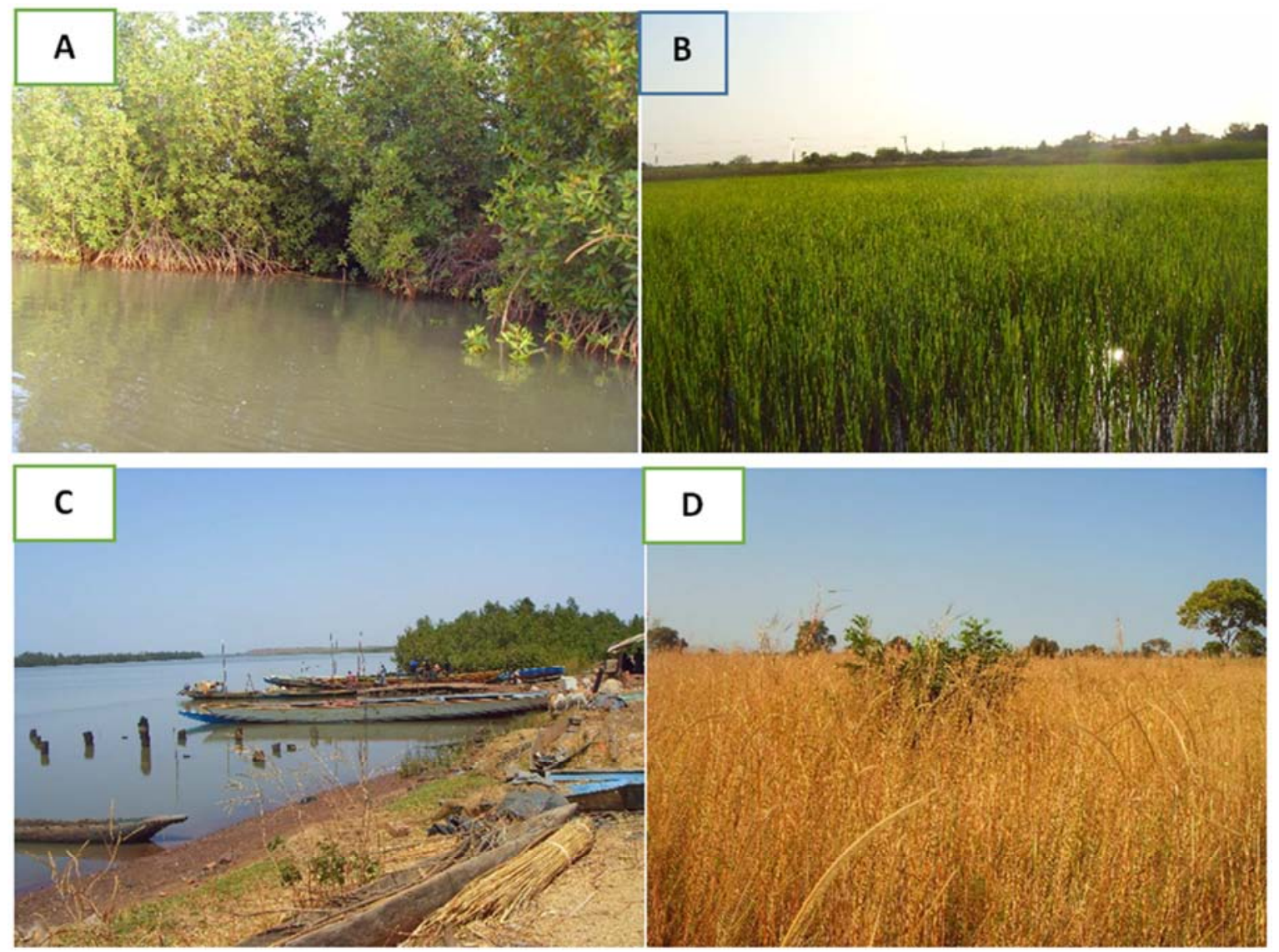

Figure 2. Pictorial view of the prominent land use/land cover features in CRR, 2017. A: River side with mangroves in Kaur, B: Rice cultivation in the swamps, C: Fish landing sites showing local canoes, D: Open shrub land.

The analysis of the false color composites was based on the principle that each land use/land cover type has a specific spectral reflectance. This is indicated in the color of that particular vegetation, characterized by its phenology and structure. Therefore, false color composites were generated i.e. the false color images of TM, ETM + and OLI/TIR (Figure 3). Based on the clarity of the resultant images, the false color composite were accurate in discriminating major components such as mangrove and River Gambia. Therefore, the most discriminative colors (in TM, ETM+ and OLI/TIR) were retained to support the ground-truthing stage which is necessary for confirmation of the different types of land use/land cover (Figure 3). After this, a sample of 88 ground control points representative of the different land use types were selected and their geographical coordinates recorded to ease location in the field. 
1984

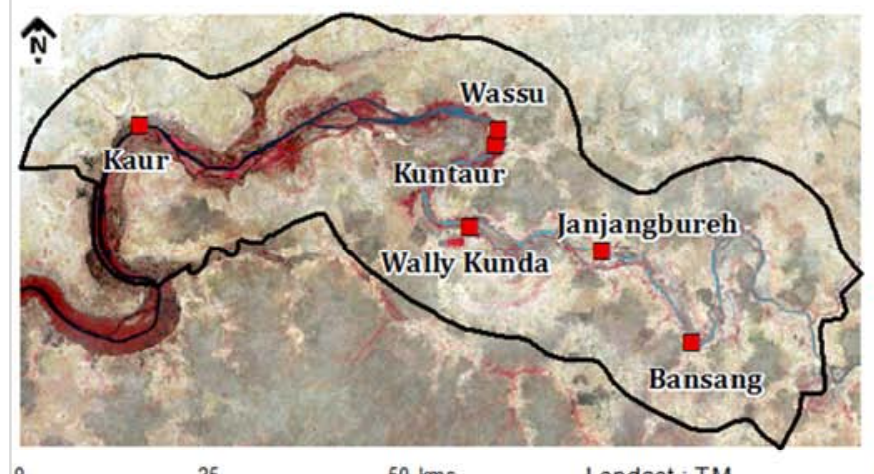

0

25

$50 \mathrm{kms}$

Landsat : TM

2007

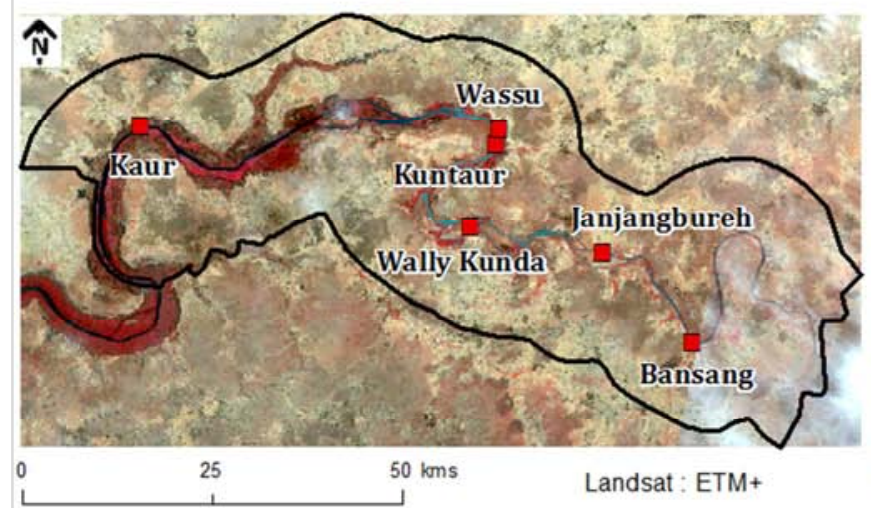

1994

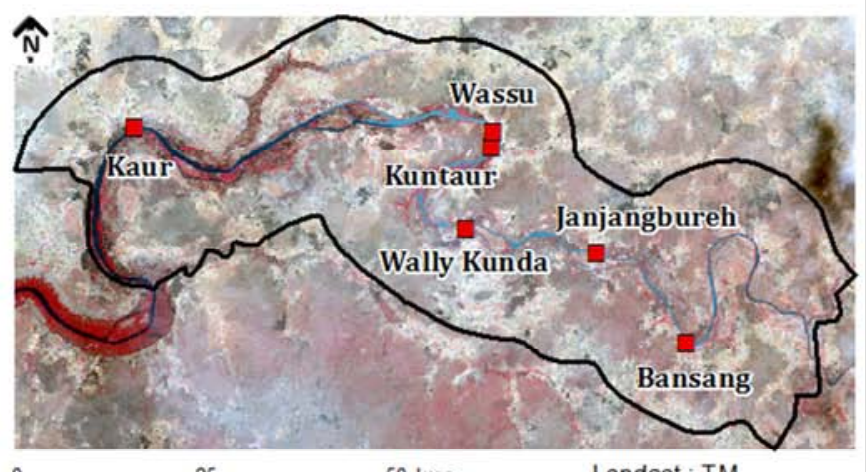

25 25 o
Landsat: TM

2017

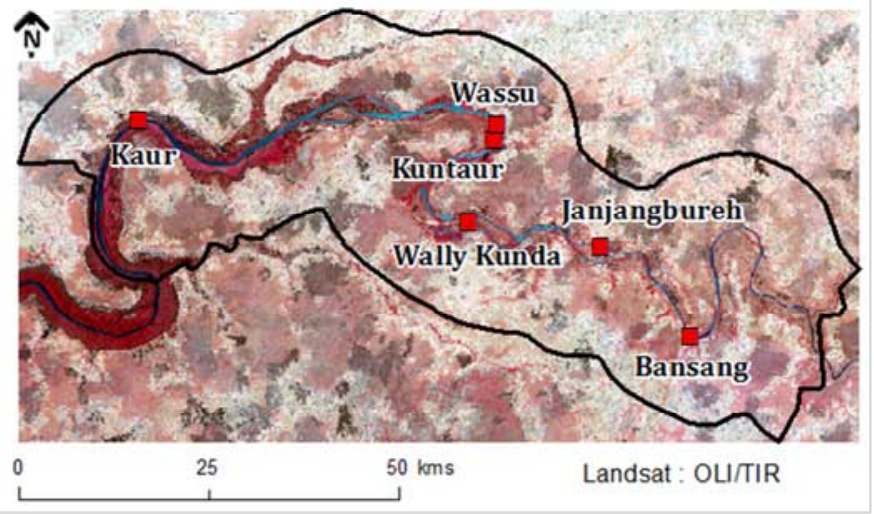

Figure 3. False color composites of Central River Region (1984-2017), TM, ETM+ and OLI/TIR.

\section{iii. Accuracy Assessment.}

Accuracy assessment is important in validating the digitally classified images. It is the procedure used to compare the classification results with the reference data that are assumed to be true [48]. Ground reference data were collected from Google Earth for 2007 and 2017 classification results. Due to a lack of old field data, ground reference data was selected on the Landsat image by an expert in Remote Sensing, GIS and in interpreting satellite images and aerial photographs. Stratified sampling (30 pixels from each class) was used to assess all classification results to evaluate the user's and the producer's accuracy and error. As a result, the producer's accuracy, user's accuracy, overall accuracy, and kappa coefficient were computed for the final land cover maps produced.

An accuracy assessment was performed in two stages: the thematic and the statistical validations based on methods of Kaufmann and Seto [48]. The thematic validation was comprised of a visual comparison between the colorcomposite and the classification results. Historical data was also used during the accuracy assessment to aid in verification of classification results.

An overall accuracy of at least $80 \%$ and a Kappa coefficient close to 1 are expected for a good classification, based on recommended assessment scale by Blum et. al [49]. After this assessment, a median filter of $3 \times 3$ pixels was applied to eliminate isolated pixels.

The classified data were then converted from raster to vector files and exported to ArcGIS for the estimation of the areas of the different land use/land cover types and the analysis of their corresponding spatial dynamics.

\subsection{Data Analysis}

\subsubsection{Socio Economic Data}

The data obtained were analyzed using Statistical Package for Social Scientists (SPSS version 23). Both descriptive statistics and linear regression analysis were used in analyzing the data. The descriptive analyses consist of tables and figures used specifically to describe the socio-economic characteristics of the respondents. The processed data were presented mostly in tabular forms to give vivid comparative analysis needed to show observable trends.

\subsubsection{Analysis of Land Cover Change}

The deforestation rate (r) was assessed within Central River Region based on the formula proposed by Puyravaud as follows [50]:

$$
r=\frac{1}{\mathrm{t} 2-\mathrm{t} 1} \ln \left(\frac{A 2}{A 1}\right)
$$

Where ' $\mathrm{r}$ ' is the deforestation rate ( $\%$ of vegetation cover lost/year); A1 and A2 represent the undegraded lands cover 
classes respectively for the periods 1984 and 2017. The undegraded land covers classes are represented here by Wooded Savanna and Shrub/wood savannah and t2-t1 is the interval in years during which change in land cover is being assessed.

\subsubsection{Analysis of Water Variables}

Individual environmental variables for all sites were subjected to a One-way Analysis of Variance (ANOVA) ( $P$ value set at $<0.05$ ) to detect significant differences per season. Pairwise student's t-test was performed using $\mathrm{R}$ software to establish seasonal differences in mean values of the water variables at individual sampling stations during the rainy and dry seasons according to methods of Hayé et. al [51].

\section{Results}

\subsection{Respondents Awareness Level of Land Cover Changes in $C R R$}

More than $95.7 \%$ of the respondents are aware that land cover changes had taken place during the last decade preceding the study period (2007-2017). Majority (84.7\%) of these respondents sought for government intervention through the department of forestry and fisheries to enforce the laws to protect our limited forest resources and fisheries respectively. Other respondents opined for support from government to provide alternatively means of income to support their families.

\subsection{Respondents Perception of the Driving Forces Causing Land Cover Changes in CRR}

Majority of the respondents $(88 \%)$ associated the land cover changes to land clearing for agriculture. Tree cutting for firewood and charcoal production accounted for the second largest culprit for land cover changes (44\%) and settlement (38\%) the third largest (Figure 4). Other minor causes of land cover changes in CRR include livestock for grazing, bush fire and timber logging.

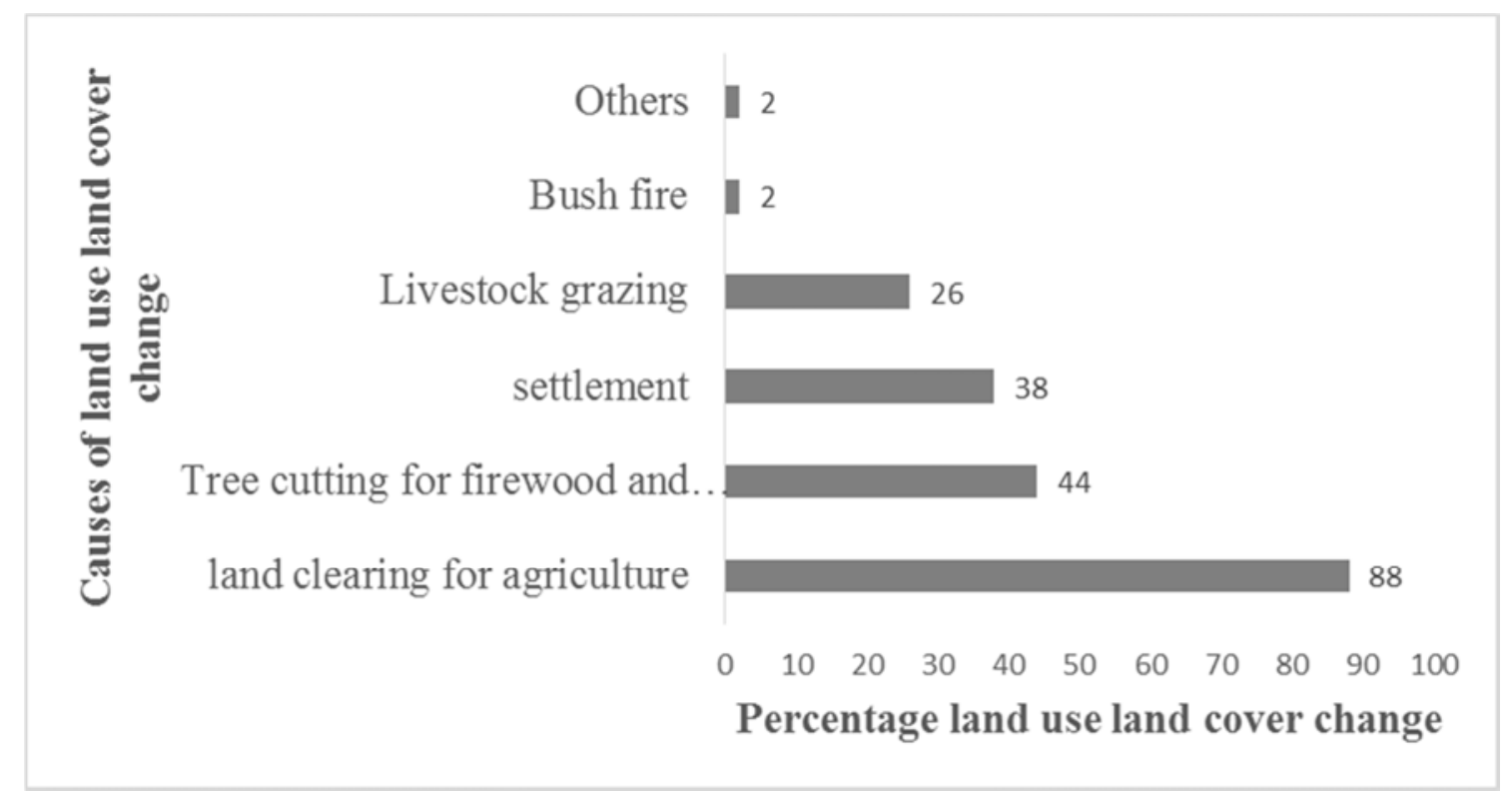

Figure 4. Factors perceived by respondents in CRR as land use land cover changes.

\subsection{State of Land Use Land Cover from 1984 to 2017}

The land use and land cover mapping identified eight classes which include Crop lands, Gambia River, Halophytic vegetation, Irrigated crops, Mangrove, Settlement, Shrub/wood savanna and Wooded savanna. The crop lands are areas corresponding to rain fed and annual farming areas (market gardening), but also include cultivated land left to rest for better soil productivity. The Gambia River corresponds to the Gambia River's minor bed covered by water and which crosses all the studied areas. The Halophytic Vegetation corresponds to the type of vegetation developing in saline environments without difficulties. The Irrigated crops mainly concerns crops that require a lot of water and are located at the beginning of The Gambia River. They generally concern fruits, vegetables and rice through rice racks. The Mangroves include families Rhizophoraceae, Acanthaceae, Lythraceae, Combretaceae and Arecaceae. They are found along the estuaries of the river Gambia. The Settlement includes construction activities along the Gambia River as well as sporadic houses within the local villages and some institutional buildings. The Shrub/wood savanna is a mixed and opened ecosystem which occurs throughout the study area and the Wooded Savanna are characterized by vegetation dominated by woody and scattered plants and is present on a good part of the study area.

The land cover statistics (Table 3) showed the dominance of crop lands, halophytic vegetation, shrub/ wood savanna and wooded savanna in 1984. This trend persisted in 1994, 2007 and 2017 which showed dominance in the same classes (Figure 5). 
Table 3. Percentage area of land cover classes in Central River Region in The Gambia, 1984-2017.

\begin{tabular}{|c|c|c|c|c|c|c|c|c|}
\hline LULC & $\begin{array}{l}\text { Area (1984) } \\
\text { ha }\end{array}$ & $\%$ & $\begin{array}{l}\text { Area (1994) } \\
\text { ha }\end{array}$ & $\%$ & $\begin{array}{l}\text { Area (2007) } \\
\text { ha }\end{array}$ & $\%$ & $\begin{array}{l}\text { Area (2017) } \\
\text { ha }\end{array}$ & $\%$ \\
\hline Crop lands & 99258,24 & 32,14 & 111333,88 & 36,06 & 131094,95 & 42,46 & 141685,53 & 45,89 \\
\hline Gambia river & 9241,32 & 2,99 & 9241,32 & 2,99 & 9241,32 & 2,99 & 9214,69 & 2,98 \\
\hline Halophytic vegetation & 41236,10 & 13,35 & 41505,06 & 13,44 & 43659,80 & 14,14 & 54651,71 & 17,70 \\
\hline irrigated crops & 7547,75 & 2,44 & 7787,60 & 2,52 & 8479,27 & 2,75 & 6011,92 & 1,95 \\
\hline Mangrove & 4587,84 & 1,49 & 4333,84 & 1,40 & 4022,84 & 1,30 & 3296,94 & 1,07 \\
\hline Settlement & 1201,70 & 0,39 & 2428,99 & 0,79 & 3083,11 & 1,00 & 3425,81 & 1,11 \\
\hline Shrub/wood savanna & 87307,70 & 28,27 & 77356,65 & 25,05 & 72843,58 & 23,59 & 69312,10 & 22,45 \\
\hline Wooded savanna & 58403,26 & 18,91 & 54796,57 & 17,75 & 36359,04 & 11,77 & 21185,21 & 6,86 \\
\hline Total & 308783,91 & 100 & 308783,91 & 100 & 308783,91 & 100 & 308783,91 & 100 \\
\hline
\end{tabular}

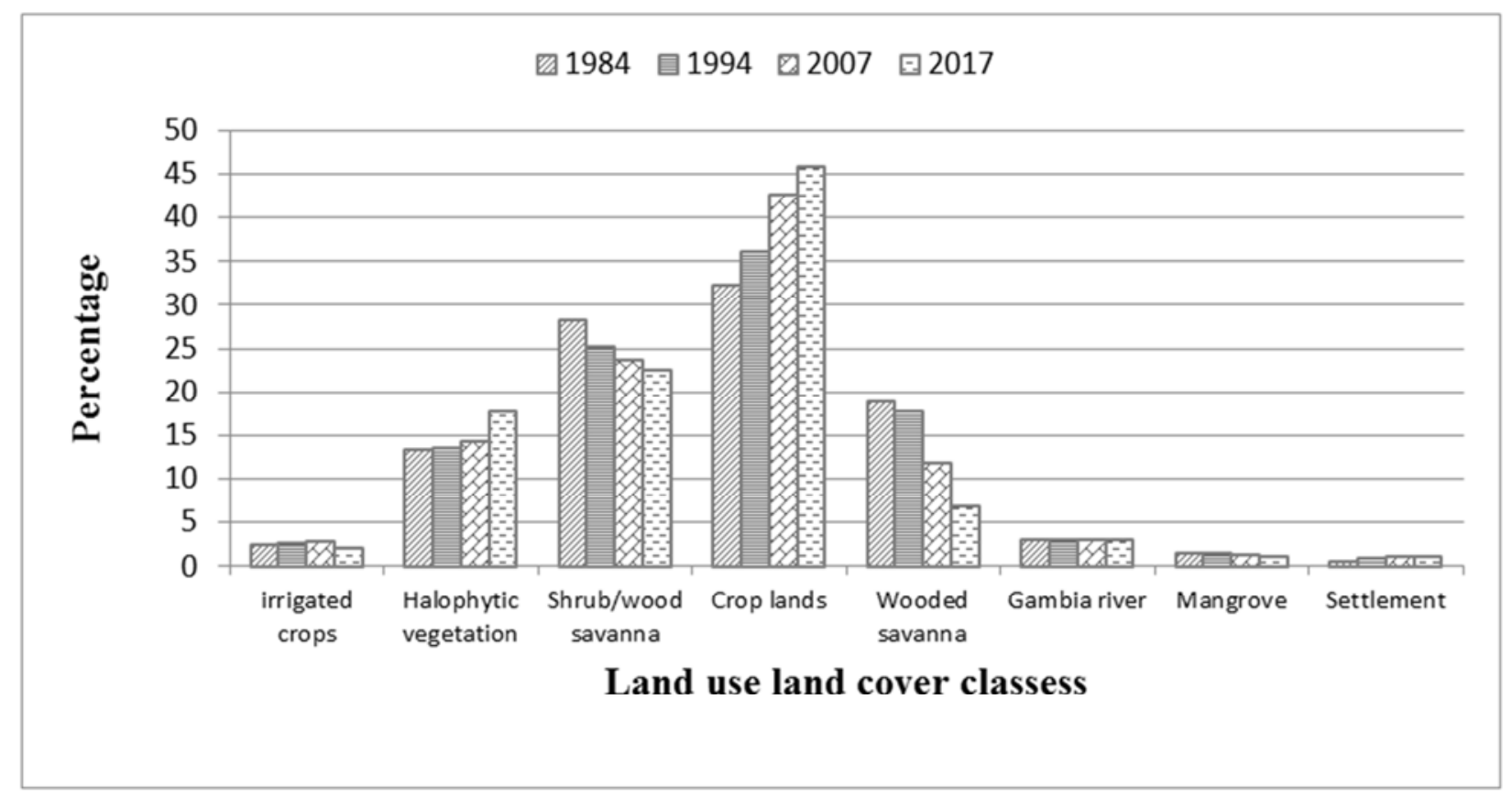

Figure 5. Percentage area of land cover classes in Central River Region in The Gambia, 1984-2017.

Table 4. Summary of land use land cover changes in Central River Region in The Gambia, 1984 to 2017.

\begin{tabular}{lllllll}
\hline \multirow{2}{*}{ LULC change } & $\mathbf{1 9 8 4 - 1 9 9 4}$ & & $\mathbf{1 9 9 4 - 2 0 0 7}$ & & $\mathbf{2 0 0 7 - 2 0 1 7}$ \\
\cline { 2 - 7 } & Area (ha) & change (\%) & Area (ha) & change (\%) & Area (ha) & change (\%) \\
\hline Crop lands & 12075,63 & 12,17 & 19761,08 & 17,75 & 10590,57 & 7,47 \\
Gambia river & 0,00 & 0,00 & 0,00 & 0,00 & $-26,63$ & $-0,29$ \\
Halophytic vegetation & 268,96 & 0,65 & 2154,75 & 5,19 & 10991,90 & 20,11 \\
Irrigated crops & 239,85 & 3,18 & 691,66 & 8,88 & $-2467,34$ & $-41,04$ \\
Mangrove & $-254,00$ & $-5,54$ & $-311,00$ & $-7,18$ & $-725,90$ & $-22,02$ \\
Settlement & 1227,29 & 102,13 & 654,12 & 26,93 & 342,70 & 10,00 \\
Shrub/wood savanna & $-9951,05$ & $-11,40$ & $-4513,07$ & $-5,83$ & $-3531,48$ & $-5,10$ \\
Wooded savanna & $-3606,69$ & $-6,18$ & $-18437,53$ & $-33,65$ & $-15173,83$ & $-71,62$ \\
\hline
\end{tabular}

During the different assessment periods, CRR was dominated by crop lands, halophytic vegetation, shrub/wood savanna and wooded savanna which totally added up to $92.67 \%$ of the area in 1984 , and $92.9 \%$ in 2017 . The River Gambia, irrigated crops, mangrove, shrub/wood savanna and wooded savanna gradually decreased between 1984 and 2017. The area covered by the River Gambia decreased from $2.99 \%$ in 1984 to $2.98 \%$ in 2017 . Irrigated crops accounted for $2.44 \%$ of the area in 1984 and this decreased to $1.95 \%$ in
2017. Mangroves decreased from $1.49 \%$ to $1.07 \%$ under the same period whereas shrub/wood savanna and wooded savanna decreased from $28.27 \%$ and $18.91 \%$ to $22.45 \%$ and $6.86 \%$ respectively. Crop lands increased from $32.14 \%$ to $45.89 \%$ showing the highest increment from 1984 to 2017. Halophytic vegetation and settlement increased by $4 \%$ and $1 \%$ respectively under the same period. The diachronic land cover maps obtained for the four periods are presented in Figure 6. 


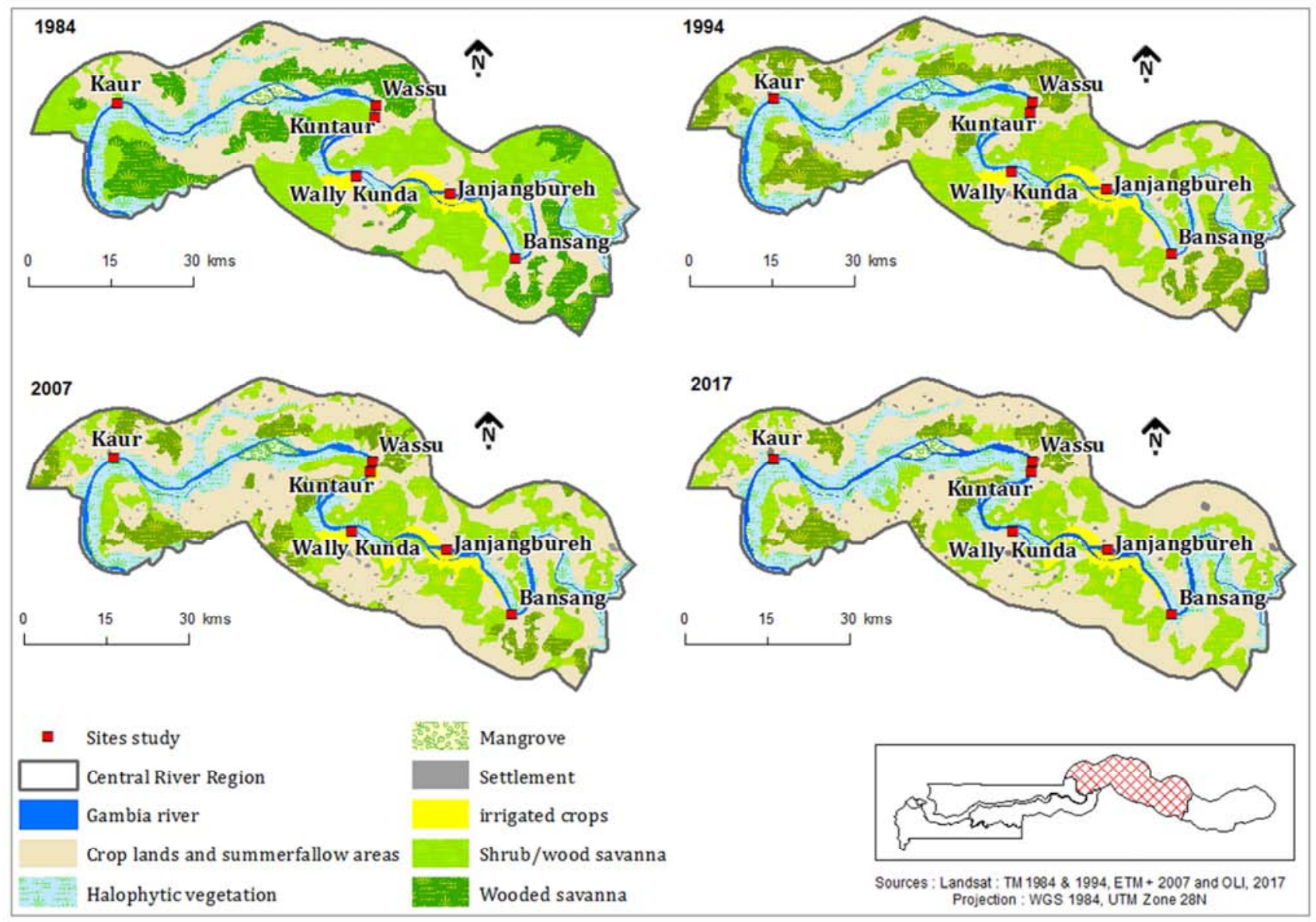

Figure 6. Land use land cover maps in CRR from 1984 to 2017.

\subsection{Land Use Land Cover Dynamics and its Relationship with Climate Variables}

The accuracy assessment was above $70 \%$ for all the images used. Kappa coefficients for the images of 1984 to 2017 recorded excellent according to the image accuracy scale of $0-1$ suggested by Blum et. al [49]. Global accuracy assessments for the images analyzed were reported in percentage as shown in the table 5 below:

Table 5. Accuracy assessment for images analyzed in CRR (1984 - 2017).

\begin{tabular}{lll}
\hline Year & Accuracy (\%) & Kappa Coefficient \\
\hline 1984 & 76.25 & 0.72 \\
1994 & 78.69 & 0.75 \\
2007 & 81.66 & 0.79 \\
2017 & 98.00 & 0.88 \\
\hline
\end{tabular}

According to the accuracy scale, the assessment of the remotely sensed data yielded eight LULC types in CRR. These include: Crop lands, Gambia River, Halophytic vegetation, Irrigated crops, Mangrove, Settlement, Shrub/wood savanna and Wooded savanna (Figure 2). Crop lands was the largest LULC class, forming $32.14 \%$ of total area coverage in 1984 and increase by $13.75 \%$ in 2017 . Shrub/wood savanna was the second largest class covering $28.27 \%$ in 1984 and this decreased by $5.82 \%$ in 2017 . The third largest class was the Wooded savanna which recorded
$18.91 \%$ in 1984 and decreased by $12.05 \%$ in 2017 . On the other hand, Halophytic vegetation which is the fourth largest class covering $13.35 \%$ in 1984 increased to $17.70 \%$ in 2017 (Tables 3 and 4).

From the decadal point of view, the area coverage for Crop lands was stable during the first two decades studied, with a slight increase of $5.58 \%$ between the years $1994-2007$ and this decrease by $10.28 \%$ from 2007 - 2017. The River Gambia was stable during the two decades with a slight decrease of $0.29 \%$ in the last decade (2007-2017). Wooded savanna decrease continuously during the three decades from 1984-2017 as follows: $6.18 \%, 33.65 \%$ and $71.62 \%$ from 1984-1994, 1994-2007 and 2007-2017 respectively. It is worth to note that, Settlement in CRR decrease constantly during the period under review by $65.2 \%$. The Halophytic vegetation was the only LULC type that registered a significant increase throughout the period in area coverage $(25.95 \%)$ as seen in table 4 .

In relation to historical data of climate variables (rainfall and atmospheric temperatures) of Sapu, some land use land cover in CRR increased and others decreased as rainfall declined and atmospheric temperatures increased. The areas of crop lands, halophytic vegetation and settlement expanded between 1984 and 2017. River Gambia, irrigated crops, mangrove, shrub/wood savanna and wooded savanna areas decreased during the same period. Transition to less savanna 
was higher than transition to more settlement. Historical climate data showed that rainfall for Sapu was quite positive before 1980. During this period, the rainfall for Sapu was always above $800 \mathrm{~mm}$. Mean annual temperature for Sapu followed a similar trend to rainfall, which recorded a minimum of 20 celcius and a maximum of 35 Celsius (Figure 7 and 8) respectively.

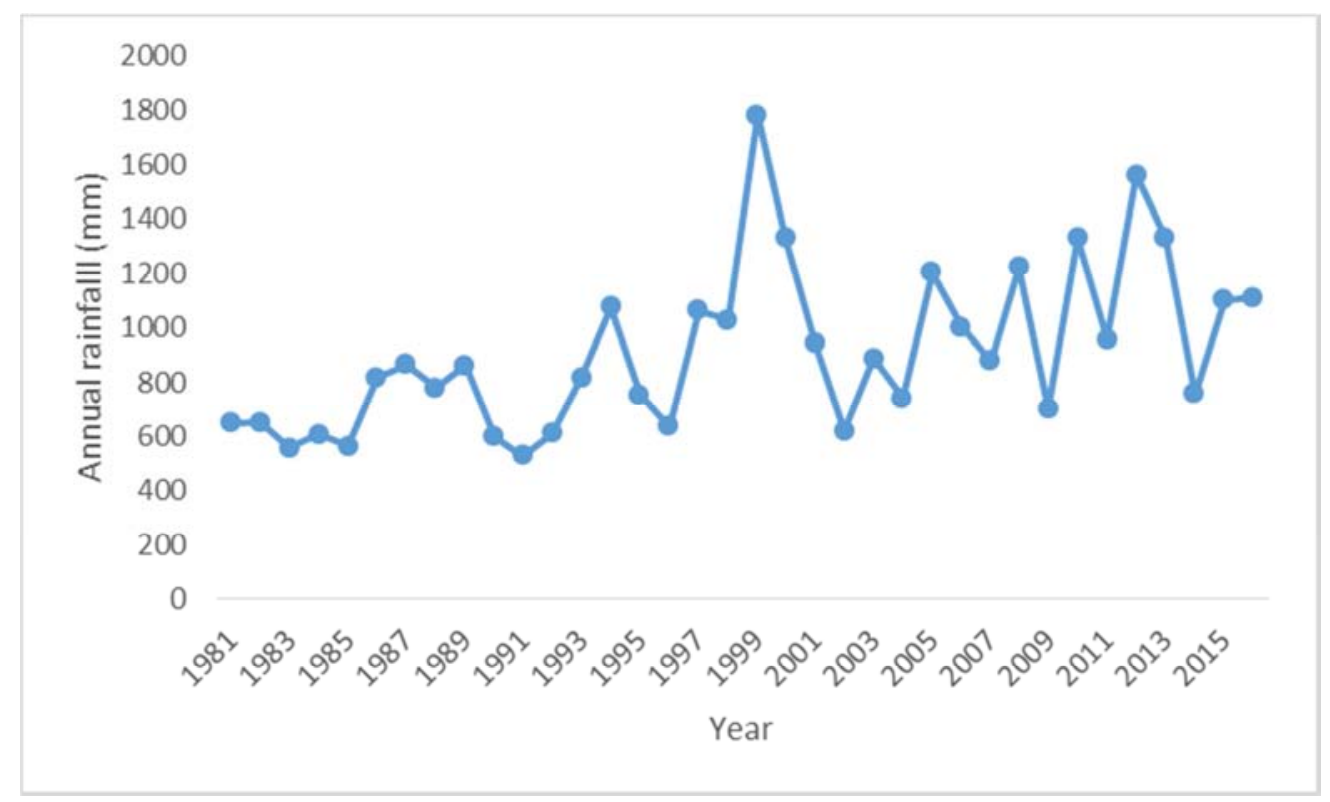

Figure 7. Long-term rainfall pattern for Sapu, 1982-2016 (Data source: The Gambia Meteorological Bureau, 2017).

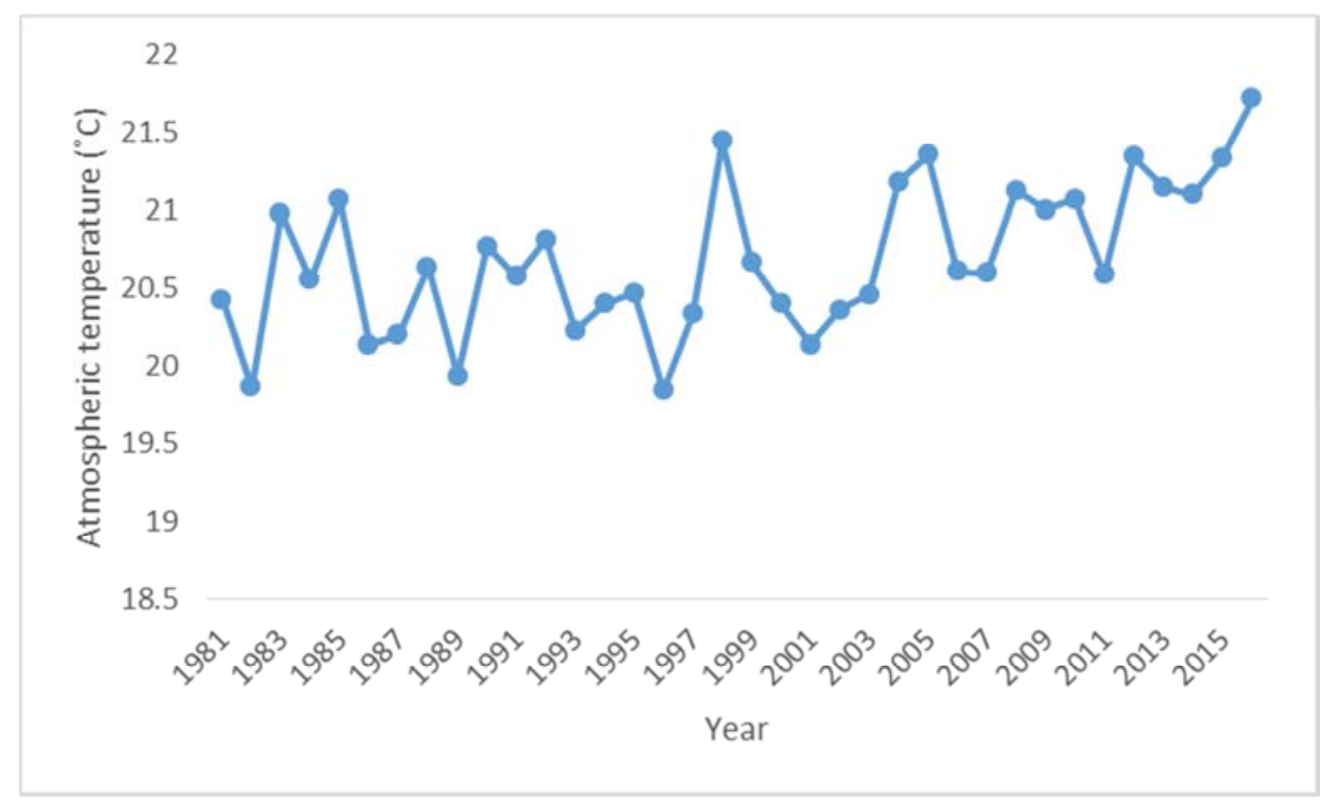

Figure 8. Long-term maximum atmospheric temperature pattern for Sapu, 1982-2016 (Data source: The Gambia Meteorological Bureau, 2017).

\subsection{Environment/Water Quality}

The one-way ANOVA showed that significant differences were recorded in conductivity levels during the two seasons under reviewed $(P$ value $<0.0001)$. Average conductivity of $81.35(\mu \mathrm{S} / \mathrm{cm})$ was recorded during the rainy season. This value increased to $1200(\mu \mathrm{S} / \mathrm{cm})$ during the dry season. The average water temperature increased significantly $(P$ value, $<0.001$ ) from $28.47^{\circ} \mathrm{C}$ during the rainy season to $33.1^{\circ} \mathrm{C}$ during the dry season.

Average $\mathrm{pH}$ levels did not differ significantly between the two seasons, i.e. 7.02 and 7.35 for the rainy and dry seasons respectively. Average Dissolved Oxygen was $4.96 \mathrm{mg} / \mathrm{L}$ during the rainy season, slightly increasing to $5.24 \mathrm{mg} / \mathrm{L}$ during the dry season. Average turbidity were 26.59 NTU during the rainy season and this decreases significantly to 15.2 NTU during the dry season. Total Dissolved Solid were 52.48 and 45.32 in the rainy and dry seasons respectively.

Significant differences were noted in nitrate and phosphate levels between the two seasons $(P$ value, $<0.003)$. Average nitrate level declined from $1.28 \mathrm{mg} / \mathrm{L}$ during the rainy season to $0.9 \mathrm{mg} / \mathrm{L}$ in the dry season. Similarly, average phosphate 
level declined significantly $(P$ value, $<0.005)$ from $0.66 \mathrm{mg} / \mathrm{L}$ during the rainy season to $0.3 \mathrm{mg} / \mathrm{L}$ during the dry season.

Average ammonia level were $0.58 \mathrm{mg} / \mathrm{L}$ during the rainy season and $0.45 \mathrm{mg} / \mathrm{L}$ during the dry season and average nitrite level were negligible throughout the study period ranging from $0.02 \mathrm{mg} / \mathrm{L}$ to $0.01 \mathrm{mg} / \mathrm{L}$ (Table 6).

Table 6. Summary of water variables and their significance levels during the rainy and dry seasons in Central River Region of The Gambia in $2017 / 2018$.

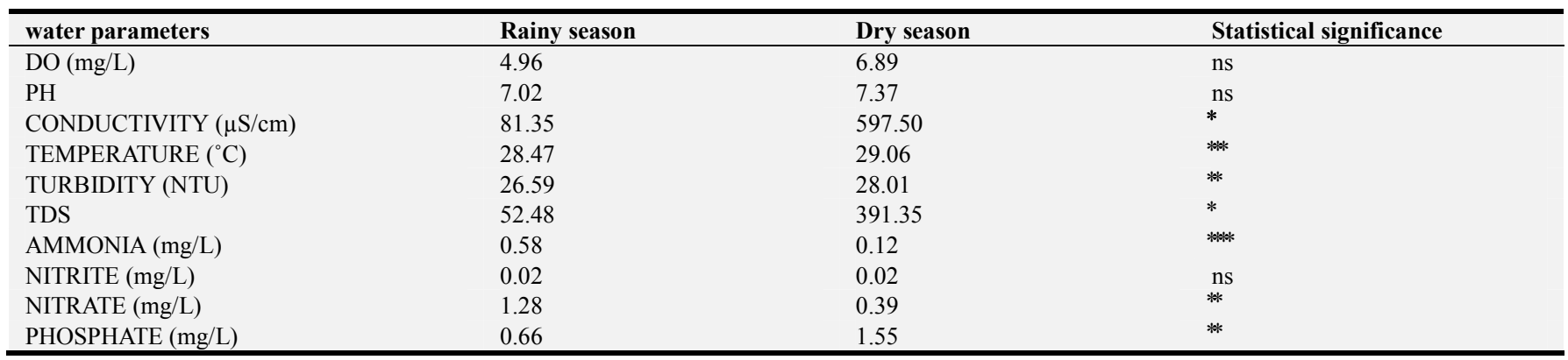

Number of stars indicates significance level. *: significant at $<0.05, * *$ : significant at $<0.01$, ***: significant at $<0.001$, $* * * *$ : significant at $<0.0001$, ns: not significant.

\section{Discussion}

\subsection{Respondents Perception of Land Use Land Cover Change}

The research revealed that land use land cover changes existed in CRR. However, this is difference in terms of age, among the respondents, the elderly people were the one who perceived more changes compared to the younger one. This is in line with Lykke et. al who states that land use land cover changes requires long time experience which elderly people possess [52]. Majority of the respondents described a negative trend of land use land cover change. This findings is in conformity with other earlier research on local perceptions of land use land cover dynamics [19, 53- 55].

\subsection{Land Use Land Cover Change Dynamic}

Land clearing for agricultural purposes is the major driving force for land use land cover changes in CRR. Our result is similar to the one obtained by Lambin et. al and Wood et. al in which agriculture remains the principal factor inducing land use land cover in Sub-Saharan Africa [12, 56,]. In contrast to our findings, Arouna et. al postulated that charcoal production is the main activity leading to land use land cover changes in central Benin [57]. Intensive fires and declining rainfall were reported in neighbouring Sine Saloum of Senegal by Lykke [58].

The household active population size affected significantly the household decision to clear new land for agriculture. Indeed, the internal growth of the household population involves more persons to be supported by the household; so that more revenue and food production are required. As response to this requirement, farmers often decide to clear new field in order to overcome their household charge increasing who concluded in their study at a strong correlation between the population growth and land degradation $[59,60]$. It is worth to note that, settlement in CRR decrease constantly during the period under review by $65.2 \%$. This may be attributed by rural-urban migration in search for greener pastures and social amenities like better education, white-colored jobs, better held facilities, water, electricity etc. which are mainly concentrated in the urban centres in The Gambia.

\subsection{Environment/Water Quality}

There is a need for a balanced water budget i.e. one where rainfall equilibrates evaporation on a yearly basis, so that key variables such as conductivity would remain stable between successive years [61]. Some research has been done on land use land cover in West Africa as a whole but as far as we know no such research have been ever conducted in Central River Region of The Gambia [59, 62]. Our research has shown that seasonal conductivity variations are more pronounced in CRR of the River Gambia [63, 64]. The freshwater water zone of the River Gambia extends from about $220 \mathrm{~km}$ around Kaur in CRR. This however, is affected by salt water intrusion during dry season which flows from the estuary of the river. Therefore, the high seasonal variation recorded in conductivities during rainy and dry seasons may be due to salt water runoff which allows sea water to intrude in CRR thus increasing the conductivity level of this area [61]. Average water temperatures in CRR during this study were 28.47 and $32^{\circ} \mathrm{C}$ for the rainy and dry seasons respectively but these values greatly differ from long time research done by Darboe where he obtained lesser amount of water temperatures in River Gambia [44]. This indicated that higher overall temperatures and lesser cooling effect from river flow as the region's water budget has become very low [65]. Our findings are also different from the one obtained by Ceesay et al. were they got 23 and $30^{\circ} \mathrm{C}$ during the rainy and dry seasons respectively in Tanbi Wetland National Park located at the estuary of the River Gambia though [37]. With predictions of Pagés and Citeau that about $80 \%$ of the increase in estuarine salinity within the Sahel is explained by long-term variability in rainfall and evaporation, similar scenario can hold for conductivity in CRR of the River Gambia [61].

Nutrient concentrations in estuaries and rivers differ according to surrounding land use, season, and geology [66]. The nutrient levels recorded during this research were way 
below the critical point, ruling out pollution as an ecosystem destabilizer in CRR. While ruling out excess nutrients being released from land uses such as agriculture and settlement, this also points to a possible situation of nutrient deficiency, which has great implications for vegetation. Nitrogen and phosphorus in particular are of great importance as they are essential in the growth of aquatic plants [37].

\section{Conclusion}

Majority of respondents in the six communities describe a negative trend of land use land change in CRR and identified the vegetation as declining. Land clearing for agriculture, tree cutting for firewood and charcoal production, and settlement were identified as lead drivers of land use land cover change dynamics which are confirmed by literature. Our research had shed light on the local perceptions of land use land change dynamics and the factors driving those changes. This means there is a need to define best management practices in order to control the agricultural clearing of land in the region. Such practices could be agricultural intensification and soil fertility improvement which may help to increase crop productivity thereby allowing farmers to produce more without clearing more land.

Temporal maps analysis in our study showed detecting change occurring in land cover during the period under reviewed. Notwithstaning, other scenarios may appear more precise for comprehending LULC dynamics and will enable long time assessment of land cover. Therefore further research is necessary for the simulation of land use land cover change in CRR.

\section{Acknowledgements}

This research was sponsored by the German Federal Ministry of Education and Research (BMBF) through the West African Science Service Center on Climate Change and Adapted Land Use (WASCAL), as part of the Graduate Research Program on Climate Change and Biodiversity at the Université Felix Houphouët-Boigny, Cote d'Ivoire. We express our profound gratitude to all these institutions for the opportunity and support they offered us during the course of the $\mathrm{Ph} . \mathrm{D}$. program. We also owe a great debt of gratitude to all the enumerators and respondents during the course of the field work as well as anonymous reviewers for their constructive comments.

\section{References}

[1] Yeshaneh, E., Wagner, W., Exner-Kittridge, M., Legesse, D., \& Blöschl, G. (2013). Identifying Land Use/Cover Dynamics in the Koga Catchment, Ethiopia, from Multi-Scale Data, and Implications for Environmental Change. International Journal of Geo-Information, 2, 302-323.

[2] Kadeba, A., Nacoulma, B. M. I., Ouedraogo, A., Bachmann, Y., Thiombiano, A., Schmidt, M., \& Boussim, J. I. (2015). Land cover change and plants diversity in the Sahel: A case study from northern Burkina Faso. Annals of Forest Research, 58 (1), 109-123.

[3] Nacoulma, B. M. I., Schumann, K., Traoré, S., Marcus, B. R., Karen, H., Rudiger, W., \& Thiombiano, A. (2011). Impacts of land-use on West Africa savanna vegetation: a comparison between protected and communal area in Burkina Faso. Biodiversity and Conservation. Doi: Springer [DOI 10.1007/s 10531-011-0114-0].

[4] Mayaux, P., Pekel, J.-F., Desclée, B., Donnay, F., Lupi, A., Achard, F., Nasi, R. (2013). State and evolution of the African rainforests between 1990 and 2010. Philosophical Transactions of the Royal Society B: Biological Sciences, 368 (1625), 20120300.

[5] Le, Q. B., Parkb, S. J., Vlek, P. L. G., \& Cremersc, A. B. (2008). Land-Use Dynamic Simulator (LUDAS): A multiagent system model for simulating spatio-temporal dynamics of 123 coupled human-landscape system. I. Structure and theoretical specification. Ecological I nformatics 3, $135-15$ 3.

[6] Meshesha, D. T., Tsunekawa, A., \& Tsubo, M. (2010). Continuing land degradation: cause-effects in Ethiopia's central rift valley. Land Degradation \& Development. Doi: 10.1002/Idr.1061

[7] Agarwal, C., Green, G. M., Grove, J. M., Evans, T. P. \& Schweik, C. M. (2002). A review and assessment of land-use change models: dynamics of space, time, and human choice. Department of Agriculture, Forest Service, Northeastern Research Station, Newton Square, US.

[8] Turner II, B. L., Scole, D., Sanderson, S., Fischer, G., Fresco, L. \& Leemans, R. (1995). Land-use and land-cover change. Science/Research Plan. IGBP Report No. 35 and HDP Report No. 7. International Geosphere-Biosphere Programme and the human dimensions of Global Environmental Change Programme. Stockholm and Geneva.

[9] Lambin, E. F., Turner, B. L., Geist, H. J., Agbola, S. B., Angelsen, A., Bruce, J. W.,... Folke, C. (2001). The causes of land-use and land-cover change: moving beyond the myths. Global Environmental Change, 11 (4), 261-269.

[10] Turner II, B. L., Moss, R. H. \& Skole, D. I. (1993). Relating land use and global land-cover change: a proposal for IGBP-HDP Core project. IDBP report No. 24 and HDP report No. 5.

[11] Ikpa, T. F., Debra, B. A., \& Jande, J. A. (2009). Biodiversity conservation: why local inhabitants destroy habit in protected areas. Science World Journal, 4, 22-27.

[12] Lambin, E. F., Geist, H. J., \& Lepers, E. (2003). Dynamics of land use and land cover change in tropical regions. Annual Review of Environment and resources, 28: 205241. Doi: 10.1146/annurev.energy.28.050302.105459

[13] Leemans, R., Lambin, E. F., McCalla, A., Nelson, J., Pingali, P. \& Watson, B. (2003). Drivers of change in ecosystems and their services In: Mooney, H., Cropper, A. Reid, W. (Eds.) Ecosystems and Human Well-Being: A framework for Assessment. Island Press, Washington: DC., USA.

[14] Geist, H. J., \& Lambin, E. F. (2002). Proximate Causes and Underlying Driving Forces of Tropical Deforestation. BioScience, 52 (2), 143-150. 
[15] Ouedraogo, I., Tigabu, M., Savadogo, P., Compaore, H., Ode, P. C., \& Ouadba, J. M. (2010). land cover change and its relation with population dynamics in burkina faso, West Africa. (2010). Land Degradation and Development.. Doi: 10.1002/ldr.981 www.interscience.wiley.com

[16] Hosonuma, N., Herold, M., De Sy, V., De Fries, R. S., Brockhaus, M., Verchot, L., Romijn, E. (2012a). An assessment of deforestation and forest degradation drivers in developing countries. Environmental Research Letters, 7 (4), 044009

[17] Fox, J., \& Vogler, J. B. (2005). Land-use and land-cover change in montane mainland Southeast Asia. Environmental Management, 36 (3), 394-403.

[18] Braimoh, A. K. (2004a). Seasonal migration and land-use change in Ghana. Land Degradation \& Development 15, 37 47.

[19] Damnyag, L., Saastamoinen, O., Blay, D., Dwomohb, F. K., Anglaaere, L. C. N., \& Pappinen, A. (2013). Sustaining protected areas: Identifying and controlling deforestation and forest degradation drivers in the Ankasa Conservation Area, Ghana. Biological Conservation 165, 86-94.

[20] Norris, K., Asase, A., Collen, B., Gockowksi, J., Mason, J., Phalan, B., \& Wade, A. (2010). Biodiversity in a forestagriculture mosaic-The changing face of West African rainforests. Biological Conservation, 143 (10), 2341-2350.

[21] Hansen, C. P., Lund, J. F., \& Reue, T. (2009). Neither fast, nor easy: the prospect of Reducing Emissions from Deforestation and Degradation (REDD) in Ghana. International Forestry Review, 4, 439-455.

[22] Carr, D. L. (2004). Proximate population factors and deforestation in tropical agricultural frontiers. Population and environment, 25 (6), 585-612.

[23] Foley, G., 1985. Woodfuel, deforestation and tree growing in the developing world. Energy Policy, 190-192.

[24] Kouami, K., Yaovi, N., \& Honan, A. (2009). Impact of charcoal production on woody plant species in West Africa: A case study in Togo. Scientific Research and Essay 4 (9), 881893.

[25] Arnold, M., Köhlin, G., \& Person, R. (2005). Woodfuels, livelihoods and policy interventions: changing perspectives. World Development, 34 ( $\left.n^{\circ} 3\right), 496-511$.

[26] Karekezi, S. (2002). Poverty and energy in Africa - a brief review. Energy Policy, 30, 915-919.

[27] Aguilar, R., Ghilardi, A., Vega, E., Skutsch, M., \& Oyama, K. (2012). Sprouting productivity and allometric relationships of two oak species managed for traditional charcoal making in central Mexico.. Biomass Energy, 36, 193-207.

[28] Nygård, R., Sawadogo, L., \& Elfving, B. (2004). Wood-fuel yields in short-rotation coppice growth in the north Sudan savanna in Burkina Faso. For Ecol Manage, 189, 77-85.

[29] Ribot, J. C. (1993). Forestry policy and charcoal production in Senegal. Energy Policy, 21, 543-585.

[30] Chidumayo, E. N., \& Gumbo, D. J. (2013). The environmental impacts of charcoal production in tropical ecosystems of the world: A synthesis. Energy for Sustainable Development, 17, 8694.
[31] Mwampamba, T. H. (2007). Has the woodfuel crisis returned? Urban charcoal consumption in Tanzania and its implications to present and future forest availability. Energy Policy, 35 (8), 42214234. Doi: http://dx.doi.org/10.1016/j.enpol.2007.02.010

[32] Luoga, E. J., Witkowski, E. T. F., \& Balkwill, K. (2002). Harvested and standing wood stocks in protected and communal miombo woodlands of eastern Tanzania. For Ecol Manage, 164, $15-30$.

[33] Turner II, B. L., Clark, W. C., Kates, R. W., Richards, J. F., Mathews, J. T., \& Meyer, W. B. (1990). The Earth As Transformed by Human Action: Global and Regional Changes in the Biosphere Over the Past 300 Years. UK: Cambridge University Press.

[34] Goudie, S. A. (2006). The human impact on the natural environment: 6th edition. Blackwell Publishing, USA.

[35] FAO. (2010). Global Forest Resources Assessment 2010: Final Report. FAO FORESTRY PAPER 163. Rome.

[36] Personal communication, Ceesay Ansumana, Acting Principal Scientific Officer, Department of Water Resources, The Gambia (August 15, 2017)

[37] Ceesay, A., Dibi, N. D. H., Njie, E., Wolff, M., \& Koné, T. (2017). Mangrove Vegetation Dynamics of the Tanbi Wetland National Park in The Gambia, 5 (2), 145-160. http://doi.org/10.13189/eer.2017.050209

[38] Republic of The Gambia (2014). REPUBLIC OF THE GAMBIA THE FIFTH (5 th) NATIONAL REPORT TO THE CONVENTION OF BIOLOGICAL DIVERSITY, 1-66.

[39] Gambia Bureau of Statistic (Gbos, 2013). The Gambia 2013 Population and Housing Census Preliminary Results Count, $102 \mathrm{pp}$.

[40] Yaffa, S. (2013). Loss and damage from drought in the North Bank Region of The Gambia. Loss and Damage in Vulnerable Countries Initiative, case study report. Bonn: United Nations University Institute for Environment and Human Security.

[41] Kathiresan, K., 2002. Why are mangroves degrading? Curr. Sci. $83,1246-1249$.

[42] Louca, V., Lindsay, S. W., Majambere, S., Lucas, M. C., 2008. Fish community characteristics of the lower Gambia River floodplains: A study in the last major undisturbed West African river. Freshw. Biol. 54, 254-271. http://dx.doi.org/10.1111/j.13652427.2008.02105.x.

[43] Albaret, J. J., Simier, M., Darboe, F. S., Ecoutin, J. M., Raffray, J., Luis Tito de Morais., 2004. Fish diversity and distribution in the Gambia Estuary, West Africa, in relation to environmental variables. Aquat, Living Resour. 17, 35-46. http://dx.doi.org/10.1051/alr:2004001

[44] Darboe, F. S., 2002. Fish Species Abundance and Distribution in the River Gambia Estuary Final project report. UNU—Fisheries Training Programme, Reykjavik, Iceland, p. 40.

[45] Ruelland, D., Levavasseur, F., \& Tribotte, A. (2010). Patterns and dynamics of land-cover changes since the 1960s over three experimental areas in Mali. International Journal of Applied Earth Observation and Geoinformation, 12, 11-17.

[46] Aubreville, A. (1957). Accord à Yamgambi sur la nomenclature des types africains de végétation. Bois et Forêts des Tropiques, 51, 23-27. 
[47] Hammi, S., Simonneaux, V., Alifriqui, M., Auclair, L., \& Montes, N. (2007). Evolution des recouvrements forestiers et de l'occupation des sols entre 1964 et 2002 dans la haute vallee des Ait Bouguemez (Haut Atlas central, Maroc). Secheresse 18, 271-277.

[48] Kaufmann, R. K. \& Seto, K. C. (2001). Change detection, accuracy, and bias in a sequential analysis of Landsat imagery in the Pearl River Delta, China: Econometric techniques. Agriculture, Ecosystems and Environment, 85: 95-105.

[49] Blum A., Feldmann L., Bresler F., Jounny P., Briançon S., Régent D. (1995). Intérêt du calcul du coefficient kappa dans l'évaluation d'une méthode d'imagerie. Measuring agreement as an evaluation of a diagnostic imaging. European Journal of Radiology 76 (7): 441- 443.

[50] Puyravaud, J. P. (2003). Standardizing the calculation of the annual of deforestation. Forest Ecology and Management, 177, 593-596. http://dx.doi.org/10.1016/S0378-1127 (02)00335-3.

[51] Hayé, C. V., Dongui, B. K., Pellerin, J., Trokourey, A. (2009). Pollution evaluation in the estuary bay of Bietri, Abidjan, Côte d'Ivoire. Journal of Oceanography, Research and Data, 2: 111 .

[52] Lykke, A. M., Fog, B., \& Madsen, J. E. (1999). Woody vegetation changes in the Sahel of Burkina Faso assessed by means of local knowledge, aerial photos, and botanical investigations. Danish Journal of Geography, Special Issue 2, 57-68.

[53] Ouoba, P. A., Dapola, E. C. D., \& Paré, S. (2014). Perception locale de la dynamique du peuplement ligneux des vingt dernières années au Sahel burkinabé., Vertigo-la revue électronique en sciences de l'environnement, 14 (2).

[54] Mertz, O., Mbow, C., Reenberg, A., \& Diouf, A. (2009). Farmers' Perceptions of Climate Change and Agricultural Adaptation Strategies in Rural Sahel. Environmental Management 43, 804-816.

[55] Lykke, A. M., Kristensen, M. K., \& Ganaba, S. (2004). Valuation of local use and dynamics of 56 woody species in the Sahel.,. Biodiversity and Conservation, 13, 1961-1990.

[56] Wood, E. C., Tappan, G. G., \& Hadj, A. (2004). Understanding the drivers of agricultural land use change in south-central Senegal. Journal of Arid Environments, 59, 565582. http://dx.doi.org/10.1016/j.jaridenv.2004.03.022.
[57] Arouna, O., Toko, I., Djogbénou, C. P., \& Sinsin, B. (2011). Comparative analysis of local populations' perceptions of socioeconomic determinants of vegetation degradation in sudano-guinean area in Benin (West Africa). International Journal of Biodiversity and Conservation, 3, 327-337.

[58] Lykke, A. M. (2000). Local perceptions of vegetation change and priorities for conservation of woodysavanna vegetation in Senegal. Journal of Environmental Management, 59, 107-120. http://dx.doi.org/10.1006/jema.2000.0336.

[59] Houessou, L. G., Teka, O., Imorou, I. T., Lykke, A. M., \& Sinsin, B. (2013). Land Use and Land-Cover Change at " W" Biosphere Reserve and Its Surroundings Areas in Benin Republic (West Africa), 3 (2), 87-101. http://doi.org/10.5539/enrr.v3n2p87.

[60] Orekan, V. O. A. (2007). Implementation of the local land-use and land-cover change model CLUE-s for Central Benin by using socio-economic and remote sensing data. $\mathrm{PhD}$ Dissertation. University of Bonn.

[61] Pagés, J. \& Citeau, J. (1990). Rainfall and salinity of a sahelian estuary between 1927 and 1987. Journal of Hydrology, 113: 325-341.

[62] Faye, L. C., Sambou, H., Kyereh, B., \& Sambou, B. (2016). Land Use and Land Cover Change in a Community-Managed Forest in South-Eastern Senegal Under a Formal Forest Management Regime, 5 (1), 1-10. http://doi.org/10.11648/j.ajep.20160501.11.

[63] Guillard, J., Simier, M., Albaret, J.-J., Raffray, J., Sow, I., Tito de Morais, L. (2012). Fish biomass estimates along estuaries: A comparison of vertical acoustic sampling at fixed stations and purse seine catches. Estuarine, Coastal and Shelf Science, 107: 105-111.

[64] Ecoutin, J. M., Simier, M., Albaret, J. J., Laë, R., Tito de Morais, L. (2010). Changes over a decade in fish assemblages exposed to both environmental and fishing constraints in the Sine Saloum estuary (Senegal). Estuarine, Coastal and Shelf Science, 87 (2): 284-292.

[65] Schlenk, D. \& Lavado, R. (2011). Impacts of climate change on hypersaline conditions of estuaries and xenobiotic toxicity. Aquatic Toxicology, 105 (3-4): 78-82.

[66] US EPA. (2006). Volunteer Estuary Monitoring: A Methods Manual. Second Edition., J. Ronald L. Ohrel \& K. M. Register, eds., Environmental Protection Agency (EPA), Washington DC (United States), 396 p. 